\title{
Karya Kristus Sebagai Dasar Penginjilan di Dunia Non-Kristen
}

\author{
Kalis Stevanus \\ Sekolah Tinggi Teologi Tawangmangu, Indonesia \\ Email: kalisstevanus91@gmail.com
}

\begin{tabular}{|l|l|l|}
\hline Diterima: 27 April 2020 & Direvisi: 18 Mei 2020 & Disetujui: 5 Juni 2020 \\
\hline
\end{tabular}

\begin{abstract}
Abstrak
Tulisan ini hendak menjelaskan mengenai konsep penginjilan, yang terdiri dari enam pokok bahasan, yaitu: landasan teologis penginjilan, pengertian penginjilan, hakikat penginjilan, motivasi penginjilan, pentingnya penginjilan dan terakhir tujuan penginjilan. Penelitian ini menggunakan pendekatan studi literatur dengan penyajian deskriptif. Penginjilan adalah memberitakan tentang karya Kristus yang sudah mati karena dosa-dosa manusia, dikuburkan dan dibangkitkan pada hari yang ketiga (1 Korintus 15:3-4). Yesus Kristus adalah satu-satunya jalan keselamatan bagi umat manusia. Dengan demikian, disimpulkan bahwa penginjilan tetap relevan dan mutlak dilakukan dengan bijak serta tulus oleh setiap pengikut Kristus dengan tujuan supaya setiap orang dapat menerima Yesus Kristus sebagai Tuhan dan Juruselamat, dan beroleh keselamatan. Keselamatan harus diterima secara pribadi, artinya respon yang diberikan bersifat pribadi terhadap berita Injil.
\end{abstract}

Kata-Kata Kunci: Kristus; Keselamatan; Non-Kristen; Penginjilan.

\section{Abstract}

This paper will explain the concept of evangelism, which consists of six main topics, namely: theological foundation of evangelism, the meaning of evangelism, the nature of evangelism, evangelistic motivation, the importance of evangelism and finally the purpose of evangelism. This study uses a literature study approach with descriptive presentation. Evangelism is preaching about the work of Christ who died for human sins, was buried and resurrected on the 
third day (1 Corinthians 15: 3-4). Jesus Christ is the only way of salvation for mankind. Thus, it is concluded that evangelism remains relevant and absolute carried out wisely and sincerely by every follower of Christ with the aim that everyone can accept Jesus Christ as Lord and Savior, and obtain salvation. Salvation must be received personally, meaning that the response given is personal to the gospel message.

Keywords: Christ; Evangelism; Non-Christians; Salvation.

\section{Pendahuluan}

Semangat penginjilan berhubungan erat dengan keyakinan orang Kristen pada Injil, yaitu berdasar pada karya Kristus yang telah mati sebagai kurban penebusan dosa. Keselamatan dalam Kristus adalah kekal dan sempurna karena hanya dilakukan satu kali untuk selamanya melalui kematian-Nya di kayu salib. Bila orang Kristen kehilangan keyakinannya bahwa Injil adalah berita dari Allah sebagai satu-satunya jalan manusia beroleh keselamatan, maka orang Kristen juga kehilangan semangat penginjilannya. Sebaliknya, jika orang Kristen tahu dan yakin bahwa Injil adalah berita dari Allah, maka dia akan terus dibuatnya bersemangat untuk memberitakan Injil sekalipun sulit dan banyak tantangan.

Seluruh Perjanjian Baru menyatakan dengan jelas sekali bahawa tumpuan misi itu adalah mengenai pewartaan tentang keselamatan yang dilaksanakan oleh Yesus Kristus. Misi penyelamatan Yesus Kristus telah disempurnakannya melalui kematian dan kebangkitan-Nya. Berita ini haruslah diwartakan oleh para murid-Nya sampai Dia datang kembali. ${ }^{1}$

Tantangan penginjilan masa kini adalah menghadapi fanatisme agama. Fanatisme agama memerlihatkan semangat yang tidak rasional yang bisa menggunakan kekuatan untuk memaksa orang untuk percaya dan berusaha menumpas yang tidak percaya. Fanatisme agama menciptakan penginjilan dibenci dengan sengit. Banyak orang dalam dunia dewasa ini sangat memusuhi usaha-usaha penginjilan. Oleh karena itu, sangat penting bagi orang Kristen untuk memahami dasar yang menopang aktivitas penginjilan, yaitu Injil adalah berita dari Allah. Hanya dengan demikianlah orang Kristen akan mampu

${ }^{1}$ Kalis Stevanus, “"'Mengimplementasikan Pelayanan Yesus Dalam Konteks Misi Masa Kini Menurut Injil Sinoptik"," Fidei: Jurnal Teologi Sistematika dan Praktika Vol.1, no. No.2 (Desember 2018.): 285-286. 
bertekun, setia dalam tugas pemberitaan Injil, dengan keberanian, dan kerendahan hati, meskipun banyak orang menentangnya. ${ }^{2}$

Pernyataan senada dikemukakan oleh Hannas dan Rinawaty bahwa tantangan yang dihadapi dalam penginjilan, semestinya tidak mengendurkan orang Kristen, apalagi menghentikan aktivitas Penginjilan. Sebaliknya, kesulitan, hambatan atau apa pun alasannya semestinya mendorong orang Kristen untuk berserah pada Allah untuk tetap melakukan penginjilan sembari mencari model-model penginjilan yang cocok dengan konteks pendengarnya. Orang Kristen hendaklah tetap bersemangat untuk memberitakan Injil guna memenangkan jiwa bagi Yesus Kristus yang dikerjakan oleh Roh Kudus menjadi kekuatan untuk terus antusias dalam aktivitas penginjilan. ${ }^{3}$

Penginjilan pada intinya memiliki dua elemen, yaitu universalitas dan kekhususan. Universal karena semua manusia tanpa kecuali adalah pendosa (Rm. 3:23) dan perlu ditebus oleh kasih karunia Allah (Rm. 6:23), dan bahwa Tuhan menghendaki keselamatan bagi semua suku bangsa, kebudayaan, ataupun kepercayaan (Yoh. 3:16; 1 Tim. 2:4). Secara khusus, keselamatan dari Allah datang melalui seorang Pribadi khusus, yakni Yesus Kristus, inkarnasi Allah yang unik dan menanggung seluruh dosa dunia (Yoh. 1:29; 1 Yoh. 2:2). ${ }^{4}$

Alkitab menyatakan bahwa hanya ada satu Allah yang hidup dan benar, Pencipta alam semesta, Allah seluruh dunia, Tuhan bangsa-bangsa dan Allah dari semua jiwa manusia. Nabi Yesaya berkata, "Terlalu sedikit bagimu hanya untuk menjadi hamba-Ku, untuk menegakkan suku-suku Yakub dan untuk mengembalikan orang-orang Israel yang masih terpelihara. Tetapi Aku akan membuat engkau menjadi terang bagi bangsa-bangsa supaya keselamatan yang dari pada-Ku sampai ke ujung bumi“" (Yes. 49:6). Paulus juga meneguhkannya di dalam Roma 3:29, "Atau adakah Allah hanya Allah orang Yahudi saja? Bukankah Ia juga adalah Allah bangsa-bangsa lain? Ya, benar. Ia juga adalah Allah bangsa-bangsa lain!

Ayat-ayat di atas dengan jelas menunjukkan bahwa keselamatan yang dari Allah Israel itu bersifat "universal" yang diperuntukkan sampai ke ujung bumi. Ketika Yesus datang, Ia mengesahkan janji-janji ini. Memang, benar, selama pelayanan-Nya di bumi, Ia terbatas untuk sementara "kepada domba-domba

${ }^{2}$ Kalis Stevanus, Benarkah Injil Untuk Semua Orang (Yogyakarta: Diandra Kreatif, 2019), 75.

${ }^{3}$ Hannas dan Rinawaty, "Menerapkan Model Penginjilan Pada Masa Kini” KURIOS," Jurnal Teologi dan Pendidikan Agama Kristen 5, No. 2 (2019): 175.

${ }^{4}$ Kalis Stevanus, Panggilan Teragung: Pedoman Dan Metoda Praktis Untuk Memberitakan Kabar Baik Sampai Ke Ujung Bumi (Yogyakarta: Andi Offset, 2019),74 
yang hilang dari umat Israel" (Mat. 10:6; Mat. 15:24). Selanjutnya, setelah kebangkitan-Nya dan sebelum kenaikan-Nya ke surga, Ia memerintahkan para pengikut-Nya untuk menjadikan semua bangsa murid-Nya. Yesus mengutus mereka ke seluruh muka bumi untuk memberitakan Injil kepada semua bangsa (Mat. 28:18-20). Rasul Yohanes menegaskan hal ini bahwa Dialah (Yesus) benar-benar Juru Selamat dunia (Yoh. 4:42). Itulah yang dilakukan oleh orang Kristen mula-mula, mereka menjadi saksi Yesus bahkan sampai ke ujung bumi, yaitu dunia non Kristen (Kis. 1:8).

\section{Metode Penelitian}

Penelitian dilakukan dengan studi literatur yang menggali berbagai konsep dan teori tentang penginjilan dan disajikan secara deskriptif. Pertama-tama dilakukan penggalian terhadap pengertian penginjilan, hakikat penginjilan, motivasi penginjilan dan pentingnya penginjilan serta tujuan penginjilan. Kemudian, penelitian diarahkan untuk menunjukkan relevansinya penginjilan dalam rangka menyebarkan Injil keselamatan di dalam Yesus Kristus di dunia non-Kristen.

\section{Pembahasan dan Hasil}

Perintah untuk memberitakan Injil atau yang biasa disebut Amanat Agung Tuhan Yesus dicatat dalam empat Injil, yaitu Matius 28:16-20, Markus 16:15-18, Lukas 24:44-49, Yohanes 20:19-23; dan Kisah Para Rasul yaitu pasal 1:6-8. Kelima bagian ini ditulis oleh empat orang penulis dalam visi dan segi yang berbeda namun semuanya saling melengkapi. ${ }^{5}$ Kelima bagian kitab tersebut hendak mengatakan bahwa Injil itu bersifat universal, karena Injil Kristus bukan hanya ditujukan bagi orang tertentu saja tetapi bagi semua orang segala suku bangsa pada segala zaman. Itu sebabnya, para murid diperintahkan agar pergi ke seluruh dunia untuk mewartakan Injil. Inisiatif penginjilan berasal dari Tuhan, bukan manusia. Dengan demikian, sangat jelas bahwa perintah penginjilan adalah produk ilahi, bukan produk gereja atau orang Kristen, tapi berasal dari Tuhan Yesus sendiri.

Sebelum membahas aktivitas penginjilan, terlebih dahulu perlu memahami

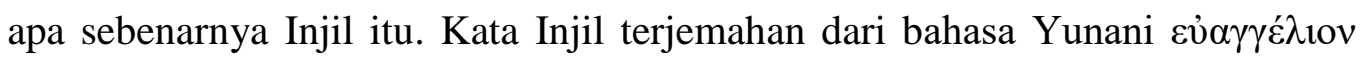
(Rm. 1:16), yaitu terdiri dari dua kata: $e u$ berarti indah atau baik dan anggelion

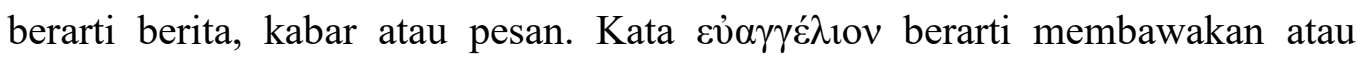

\footnotetext{
${ }^{5}$ Yakob Tomatala, Penginjilan Masa Kini 1 (Malang: Gandum Mas, 2004), 25-26.
} 
menyampaikan/mengumumkan kabar baik. Berarti Injil adalah kabar baik. ${ }^{6}$ Charles H. Spurgeon juga menyatakan Injil adalah kabar baik. Dalam Injil ada informasi yang perlu diketahui manusia dan pernyataan-pernyataan yang akan memberkati mereka yang bersedia mendengarkan. ${ }^{7}$ Dapat dikatakan secara etimologi, Injil berarti kabar baik. Hal ini juga diungkapan Rasul Paulus tentang Timotius, "Ia seorang pelayan Allah yang bekerja bersama kami untuk memberitakan Kabar Baik tentang Kristus" (1 Tes. 3:2 - BIS). Penginjilan adalah sebuah berita atau kabar baik tentang Kristus. Dengan demikian, istilah "penginjilan" mencakup segala usaha untuk memberitakan Kabar Baik tentang Yesus Kristus. Itulah pengertian penginjilan secara sempit.

Sedangkan defisini penginjilan secara konseptual dan lebih luas adalah dari pernyataan ikrar kongres tentang penginjilan Dunia tahun 1974 di Lausane yang dihadiri lebih dari 150 bangsa, yang dikutip oleh Scheunemann (seorang Misionaris dari Jerman yang melayani di bawah naungan Yayasan Pelayanan Pekabaran Injil Indonesia Batu Malang). Penginjilan atau memberitakan Injil adalah menyebarluaskan kabar baik bahwa Yesus Kristus telah mati untuk dosadosa manusia dan bangkit di antara orang mati sesuai dengan Alkitab, dan bahwa sebagai Tuhan yang memerintah, Ia sekarang menawarkan pengampunan dosa dan pembebasan oleh Roh kepada semua orang yang bertobat dan percaya. ${ }^{8}$ Lukas mencatat di dalam Injilnya demikian, "Kata-Nya kepada mereka, "Ada tertulis demikian: Mesias harus menderita dan bangkit dari antara orang mati pada hari yang ketiga, dan lagi: dalam nama-Nya berita tentang pertobatan dan pengampunan dosa harus disampaikan kepada segala bangsa, mulai dari Yerusalem" (Luk. 24:46-47). Sejatinya orang Kristen itu sebagai penyambung lidah Allah untuk menyampaikan berita pengampunan Allah kepada manusia berdosa. ${ }^{9}$

Pendapat lain, yaitu Packer memberikan tambahan cakupan dari penginjilan. Packer yang dikutip oleh Thomy J. Matakupan, mendefinisikannya, "penginjilan adalah proklamasi karya keselamatan yang dikerjakan Kristus melalui kematian dan kebangkitan-Nya, di dalam kuasa Roh Kudus dan menuntut adanya tanggapan pribadi, yaitu bertobat, beriman, dan menerima-Nya

${ }^{6}$ Kalis Stevanus, Benarkah Injil Untuk Semua Orang (Yogyakarta: Diandra Kreatif, 2019), 111.

${ }^{7}$ Charles H. Spurgeon, Strategi Jitu Untuk Menjadi Pemenang Jiwa (Yogyakarta: Andi, 2019), 9.

${ }^{8}$ V. V. Scheunemann, Apa Kata Alkitab Tentang Dogma Kristen (Malang: YPPII, 1992), 163

${ }^{9}$ J. I. Packer, Penginjilan Dan Kedaulatan Allah (Surabaya: Momentum, 2003), 29 
sebagai Juruselamat; serta menjadi murid yang rela menyangkal diri, memikul salib, dan melayani Dia." 10

Rasul Paulus menjelaskan atau meringkaskan "esensi" Injil kepada jemaat di Korintus demikian, "Dan sekarang, saudara-saudara, aku mau mengingatkan kamu kepada Injil yang aku beritakan kepadamu dan yang kamu terima, dan yang di dalamnya kamu teguh berdiri. Oleh Injil itu kamu diselamatkan, asal kamu teguh berpegang padanya, seperti yang telah kuberitakan kepadamu-kecuali kalau kamu telah sia-sia saja menjadi percaya. Sebab yang sangat penting telah kusampaikan kepadamu, yaitu apa yang telah kuterima sendiri, ialah bahwa Kristus telah mati karena dosa-dosa kita, sesuai dengan Kitab Suci, bahwa Ia telah dikuburkan, dan bahwa Ia telah dibangkitkan, pada hari yang ketiga, sesuai dengan Kitab Suci' (1 Kor. 15:1-4). Ditambahkan oleh Howard G. Hendricks bahwa yang menjadi "esensi" dari Injil sekaligus "keajaiban” Injil adalah, "Karena Kristus telah mati mengganti kita, maka kita tidak perlu binasa. Kristus telah mati sekali untuk segala dosa kita supaya Ia membawa kita kepada Allah (1 Ptr. 3:18) ... supaya jangan ada yang binasa, melainkan supaya semua orang berbalik dan bertobat ( 2 Ptr. 3:9)."11

Dari uraian di atas, penulis menyimpulkan bahwa penginjilan adalah sebuah aktivitas untuk memberitakan Injil yaitu kabar baik kepada personal maupun kelompok (massa). Berita Injil adalah kabar baik bahwa Allah di dalam kasih-Nya yang tidak terbatas menyediakan pengampunan bagi manusia berdosa melalui kematian Yesus Kristus di kayu salib untuk menebus dosa manusia. Tanpa karya penebusan Kristus di kayu salib, tidak ada pengampunan dosa bagi manusia berdosa. Sebab itu, manusia berdosa harus menentukan secara pribadi sikapnya terhadap undangan Injil (penginjilan) untuk menerima Yesus Kristus sebagai Juruselamat dan Tuhan serta mengikuti Dia dan bersedia menyangkal diri sebagai murid Kristus.

\section{Hakikat Penginjilan}

Injil adalah kabar baik yang telah dipercayakan kepada setiap orang Kristen. Alkitab memaparkan dengan jelas bahwa semua orang Kristen adalah saksi Kristus (Kis. 1:8; 2 Kor. 5:20) yang diberi Amanat Agung (Mat. 28:18-20; Mrk. 16:15). Setiap orang Kristen memiliki tanggung jawab yang sama untuk

\footnotetext{
${ }^{10}$ Thomy J. Matakupan, Prinsip-Primsip Penginjilan (Surabaya: Momentum, 2002), 5

${ }^{11}$ Howard G. Hendricks, Beritakan Injil Dengan Kasih (Jakarta: BPK Gunung Mulia, 2008), 24.
} 
menjadi saksi yang baik dan bertanggung jawab dalam mengabarkan Injil kepada orang lain, yakni dunia non-Kristen. ${ }^{12}$

Berita Injil adalah kabar baik bahwa Allah di dalam kasih-Nya yang tidak terbatas menyediakan pengampunan bagi manusia berdosa berdasarkan karya penebusan Yesus Kristus di kayu salib. Hanya melalui Yesus Kristus, tiada jalan lain yang dapat membawa seseorang kembali berdamai dengan Bapa di surga. Injil memberikan pengharapan dan kehidupan kekal bagi setiap orang percaya. Janji penebusan tersebut bersumber pada Allah Tritunggal di dalam kekekalan telah berencana untuk menyelamatkan orang berdosa sebelum dunai diciptakan (Kis. 2:25-28; Ef. 1:3-4; 3:8-11; Tit. 1:2-3; I Ptr. 1:18-20). ${ }^{13}$ Dengan demikian, Allah-lah yang berinisiatif untuk menyelamatkan manusia berdosa melalui diri Yesus Kristus. Ia memanggil manusia berdosa ke dalam keselamatan. Karya keselamatan tersebut merupakan karya Allah Tritunggal.

Berdasarkan uraian di atas, dapat dijabarkan hakikat penginjilan adalah berita tentang: pertama, keselamatan adalah anugerah Allah. Keselamatan adalah karya Allah Tritunggal, bukan manusia (Ef. 2:8-10). Sentralitas dari Injil Yesus adalah keselamatan. Allah dalam Alkitab adalah Allah yang terus menyelamatkan manusia berdosa untuk menjadi umat-Nya, yang mengambil inisiatif untuk menyelamatkan. Misi Yesus adalah misi untuk menyelamatkan. Dia "datang ke dunia untuk menyelamatkan orang berdosa" (1 Tim. 1:15). "Bapa telah mengutus Anak-Nya menjadi Juruselamat dunia" (1 Yoh. 4:14). Nama-Nya sendiri sudah menunjukkan misi-Nya, karena "Yesus" berarti "Allah Juruselamat" atau "Allah adalah keselamatan" (Mat. 2:21), dan sebutan lengkapNya adalah "Tuhan dan Juruselamat kita, Yesus Kristus" (2 Ptr. 3:18). ${ }^{14}$

Penulis menyimpulkan keselamatan adalah anugerah, tidak bermaksud mengatakan bahwa Allah akan menyelamatkan manusia berdosa tanpa para utusan Injil dan respon pendengar. Keselamatan adalah anugerah, tidak berarti bahwa manusia berdosa tidak memiliki tanggung jawab sama sekali di dalam hal keselamatannya. Jelas dari fakta bahwa keselamatan datang melalui iman (Yoh. 3:16), dan iman datang dari pemberitaan Injil yang dilakukan oleh utusan-utusan Injil (2 Kor. 5:20). Sebab itu, manusia berdosa harus menyambut undangan Injil dengan percaya Kristus. Iman yang menyelamatkan ini dimengerti sebagai pemberian atau anugerah Allah semata (Fil. 2:12-13).

\footnotetext{
${ }^{12}$ Stevanus, Benarkah Injil Untuk Semua Orang, 7-8.

${ }^{13}$ Thomy J. Matakupan, Prinsip-Primsip Penginjilan, 6.

${ }^{14}$ Kalis Stevanus, Lihatlah Sang Juruselamat Dunia (Yogyakarta: Diandra Kreatif,
} 2018), 16. 
Kedua, Penginjilan adalah kabar baik tentang keselamatan dalam Kristus. Allah yang berinisiatif untuk menyelamatkan manusia berdosa berdasarkan kasih dan kedaulatan-Nya semata (Ef. 1:5; Rm. 5:8). Allah telah menebus manusia berdosa darin hukuman maut dan kebinasaan kekal, telah mendamaikan manusia berdosa dengan diri-Nya dan menganugerahkan keselamatan sehingga manusia memiliki persekutuan kembali dengan Allah.. Semua itu dikerjakan di kayu salib menggantikan tempat manusia berdosa di mana Kristus menjadi berdosa agar manusia dibenarkan Allah.

Memang benar, selama pelayanan-Nya di bumi, Kristus terbatas untuk sementara "kepada domba-domba yang hilang dari umat Israel" (Mat. 10:6; Mat. 15:24). Selanjutnya, setelah kebangkitan-Nya dan sebelum kenaikan-Nya ke surga, Tuhan Yesus memerintahkan para pengikut-Nya untuk menjadikan semua bangsa murid-Nya (Mat. 28:18-20). Yesus mengutus mereka ke seluruh muka bumi untuk memberitakan Injil kepada semua bangsa. Rasul Yohanes menegaskan bahwa "Dialah (Yesus) benar-benar Juruselamat dunia" (Yoh. 4:42).

Ketiga, panggilan pertobatan. Alkitab dengan jelas menyatakan, "Sebab karena kasih karunia kamu diselamatan oleh iman" (Ef. 2:8-10). Di sini jelas ada dua unsur vital keselamatan yaitu kasih karunia (anugerah) dan iman. Keduanya berbeda. Kalau hanya kasih karunia (anugerah) berarti keselamatan belum menjadi milik manusia berdosa (kita), namun harus ada iman. Iman adalah langkah menyambut keselamatan itu. Keselamatan yang dijelaskan di Alkitab adalah karena anugerah Allah (sola gratia) sekaligus karena iman (sofa fide). Keselamatan yang dikerjakan Alah melalui Kristus di kayu salib adalah pengorbanan yang tidak dapat dikerjakan oleh manusia siapa pun, karenanya disebut anugerah (sola gratia). Tetapi anugerah membutuhkan respon dari manusia berdosa agar menjadi terwujud dalam kehidupannya (sofa fide). ${ }^{15}$

Dari uraian di atas dengan sangat jelas dinyatakan keselamatan itu sematamata pemberian Allah, hanya karena kasih karunia Allah melalui iman, bukan karena usaha ataupun pekerjaan manusia. Tanpa anugerah Allah, manusia tidak mungkin dapat memberikan respon positif atau bertobat dan menerima keselamatan.

Jadi, Kristus mati untuk keselamatan manusia itu murni tindakan Allah semata (anugerah/kasih karunia), bukan karena manusia memenuhi syarat tertentu. Itulah yang disebut kasih karunia/anugerah. Pemberian Anak Tunggal

${ }^{15}$ Kalis Stevanus, Jalan Masuk Kerajaan Surga (Yogyakarta: Andi Offset, 2017), 65. 
Bapa kepada manusia berdosa adalah kasih karunia yang tiada tara (Yoh. 3:16). Pemberian ini berangkat dari kasih-Nya yang besar kepada manusia berdosa. Tindakan meresponi tawaran keselamatan-Nya itulah yang disebut iman. Iman adalah pihak manusia, sedangkan kasih karunia adalah pihak Tuhan. Allah yang "berinisiatif" memberikan panggilan pertobatan kepada manusia berdosa, "Bertobatlah dan percayalah kepada Injil" (Mrk. 1:15; 16:15), yang mendorong mereka untuk menerima keselamatan melalui pemberitaan Injil. Dengan kedaulatan kehendak-Nya, Allah memanggil manusia berdosa menerima keselamatan. Inilah yang disebut anugerah.

Namun demikian, anugerah Allah itu harus direspon. Anugerah bukan berarti manusia si penerima anugerah tidak memiliki langkah sama sekali untuk meraih anugerah tersebut. Kalau seseorang mendapat hadiah gratis tanpa membayar (anugerah), bukan berarti dia hanya diam saja lalu anugerah itu datang dengan sendirinya. Ia harus melangkah mengambil hadiah itu. Inilah respon, yang bisa disejajarkan dengan iman. Jika manusia bisa atau boleh diam saja menerima anugerah manusia menjadi manusia yang tidak bertanggungjawab sama sekali. Jangan berpikir diselamatkan karena anugerah lalu respon manusia tidak dibutuhkan sama sekali. Semua dikerjakan oleh Allah agar manusia tidak menjadi sombong. Itu konsep keselamatan yang keliru. Pertobatan berkaitan erat dengan respon positif terhadap undangan keselamatanNya. Dengan demikian, panggilan pertobatan (Mrk. 1:4, 15; Kis. 2:38, dll.), harus ada dalam penginjilan. Sebab pertobatan mendahului keselamatan.

Dengan demikian dapat disimpulkan bahwa jikalau manusia berdosa dapat menmberikan tanggapan berdasarkan kemauan atau kehendaknya untuk menerima anugerah keselamatan yang disediakan Allah melalui iman kepada Tuhan Yesus, maka hal itu tidak diperhitungkan sebagai upah dari perbuatan baiknya. Namun, hal itu semata-mata terjadi karena anugerah Allah yang telah bekerja di dalam diri manusia berdosa itu. Manusia di luar Kristus tidak akan mungkin melalukan perbuatan baik yang berkenan kepada Allah. Perbuatan baik yang dilakukan di luar iman, di hadapan Allah hanyalah seperti kain yang kotor (Yes. 64:4-6). Sebab perbuatan baik yang dilakukannya adalah perbuatan baik dalam status keberdosaannya. Tindakan seseorang menerima sepenuhnya berita Injil serta menjadikan Kristus sebagai Tuhan dan Juruselamat di dalam kehidupannya, disebut pengalaman beriman atau diselamatkan. Semua ini diawali pada saat seseorang mendengar berita Injil. 


\section{Motivasi Penginjilan}

Orang Kristen harus memberitakan Injil (penginjilan) secara verbal kepada orang lain, yaitu dunia orang non-Kristen sebagaimana yang dikatakan dalam Amanat Agung (Mat. 28:18-20; Mrk. 16:15). Ini adalah suatu tindakan aktif yang dilakukan untuk berbicara kepada orang lain tentang berita keselamatan di dalam Kristus. Para rasul, dimulai dari Petrus, memberitakan Injil, lalu sekitar tiga ribu orang bertobat (Kis.2), dan rasul-rasul lain serta murid-murid Kristus yang lain bukan saja bersaksi melalui kehidupan baik, melainkan juga dengan perkataan, dengan suara keras menyerukan, “... maka sekarang Allah memberitakan kepada manusia, bahwa di mana-mana semua mereka harus bertobat" (Kis. 17:30).

Mengapa harus ada penginjilan, orang Kristen harus jelas terlebih dahulu memahami apa itu motivasi. Motivasi bukanlah tujuan, dan tujuan bukan motivasi. Motivasi adalah penyebab yang menghasilkan suatu tindakan, sedangkan tujuan adalah hasil yang diharapkan dapat tercapai melalui tindakan itu. Stephen Tong mengatakan motivasi yang benar dalam penginjilan memberikan kekuatan yang besar pada saat yang paling melelahkan, dan memberi keteguhan pada waktu aniaya menimpa, memberi sukacita pada waktu kesesakan menekan. ${ }^{16}$ Hal senada juga dikatakan Matakupan, bahwa Allah melihat motivasi yang tulus dan murni pada mereka yang mengabarkan Injil. Motivasi tersebut akan menyebabkan seseorang tidak gampang menjadi kecewa dan undur ketika menjumpai berbagai macam kesulitan dalam pelayanannya. ${ }^{17}$

Berikut adalah motivasi dalam melakukan penginjilan yang penulis adaptasi dari pendapat Tong ${ }^{18}$, Metzger ${ }^{19}$ dan Matakupan. ${ }^{20}$

\section{Penginjilan Adalah Kehendak Allah}

Kehendak Allah adalah semua orang diselamatkan, "Itulah yang baik dan yang berkenan kepada Allah, Juruselamat kita, yang menghendaki supaya semua orang diselamatkan dan memeroleh pengetahuan akan kebenaran" (1 Tim. 2:34). Penginjlan merupakan kehendak Tuhan dan mutlak berasal dari diri Tuhan sendiri. Tuhan adalah "Inisiator" utama dan pertama dalam penginjilan.

\footnotetext{
${ }^{16}$ Stephen Tong, Teologi Penginjilan (Jakarta: Lembaga Reformed Injili Indonesia, 2004), 40 .

${ }^{17}$ Thomy J. Matakupan, Prinsip-Primsip Penginjilan, 8.

${ }^{18}$ Stephen Tong, Teologi Penginjilan, 41.

${ }^{19}$ Will Metzger, Beritakan Kebenaran (Surabaya: Momentum, 2013), 205-206.

${ }^{20}$ Thomy J. Matakupan, Prinsip-Primsip Penginjilan, 9.
} 
Karena memberitakan Injil adalah hal yang sudah Allah tetapkan dalam kekekalan dan dipercayakan kepada umat-Nya untuk melaksanakannya, maka Allah-lah yang "menjamin" keberhasilan penginjilan. Penginjilan adalah menjalankan kehendak Allah, maka memberitakan Injil tidak mungkin tanpa ada hasil. Ini fakta yang menghibur dan mengagumkan. Allah telah memercayakan kepada umat-Nya, para pendosa yang telah ditebus ini, tanggung jawab untuk mengerjakan maksud Allah dalam sejarah, yaitu penyelamatan manusia. Sejak Pentakosta, Roh Kudus dicurahkan, maksud penyelamatan Allah dalam sejarah sedang diwujudkan melalui umat-Nya.

\section{Penginjilan Adalah Mandat Kristus}

Amanat Agung Tuhan Yesus seperti tertulis di Matius.28:19-20; Markus 16:15-16; Lukas 24:47; Yohanes 20:21 dan Kisah Para Rasul 1:8. Setelah Tuhan Yesus menang atas kuasa maut, Dia lalu mengutus umat-Nya untuk memberitakan Injil. Kristus sendiri menjadikan diri-Nya sebagai teladan. Ia memberitakan Injil "Kerajaan Allah" (Mat. 4:23; 11:1; 9:35). Inilah yang mendasari seluruh pekerjaan penginjilan.

Perintah mengerjakan penginjilan bukan hanya diperuntukkan bagi para misionaris atau hamba-hamba Tuhan. Tapi Alkitab mengatakan dengan jelas bahwa setiap orang Kristen memiliki hak istimewa ini (Kis. 1:8,4; 2 Kor. 5:1820). Semua orang Kristen, para pengikut Kristus diberi mandat untuk melaksanakan penginjilan Injil kepada semua bangsa. Mandat ini sering disebut sebagai Amanat Agung (Mat. 28:18-20; Mrk. 16:15; Luk. 24:47). Sesudah kebangkitan, Tuhan Yesus menjanjikan kepada murid-murid-Nya bahwa mereka akan menjadi saksi (Kis. 1:8) dan memerintahkan mereka untuk melaksanakan penginjilan kepada semua bangsa. Jadi, semua orang Kristen, siapapun mereka tanpa kecuali dipanggil untuk menaati perintah penginjlan tersebut.21

Benar, ada orang-orang Kristen yang memiliki karunia/talenta yang membuat mereka cocok sekali untuk tugas penginjilan, misalnya yaitu kefasihan berbicara, mudah bertemu dan bergaul dengan orang, dan sebagainya. Namun bila ada seorang Kristen menyangka bahwa ia tidak memiliki "karunia penginjilan", ia rentan untuk menarik kesimpulan yang keliru, yaitu bahwa ia tidak memiliki tanggung jawab untuk bersaksi. Sebenarnya, Alkitab memaparkan dengan jelas bahwa setiap orang Kristen adalah saksi Kristus yang

${ }^{21}$ Kalis Stevanus,"Mengimplementasikan Pelayanan Yesus Dalam Konteks Misi Masa Kini Menurut Injil Sinoptik", Fidei: Jurnal Teologi Sistematika dan Praktika, Vol.1 No.2 (Desember 2018):285 
diberi Amanat Agung. Tuhan akan diberi kekuatan, hikmat oleh Tuhan dalam pekerjaan penginjilan ini, karena setiap orang Kristen dipanggil dan bertanggung jawab dalam mengabarkan Injil kepada dunia non-Kristen.

\section{Penginjilan Harus Dilandasi oleh Belas Kasihan Terhadap Mereka yang Terhilang}

Telah banyak cara digunakan dalam usaha mengajak orang Kristen untuk terlibat ke dalam pekerjaan penginjilan. Ada orang yang terdorong melakukan penginjilan karena ada itu suatu perintah dari Tuhan Yesus yang tak dapat ditolak sehingga terpaksa melakukannya. Ada juga yang terdorong menginjili karena akan menambah pahala di sorga.

Semua motivasi di atas adalah keliru. Firman-Nya jelas berkata, "Akan tetapi Allah menunjukkan kasih-Nya kepada kita, oleh karena Kristus telah mati untuk kita, ketika kita masih berdosa" (Rm. 5:8). Dan juga dikatakan di dalam 2 Korintus 5:14-15, "Sebab kasih Kristus yang menguasai kami, karena kami telah mengerti, bahwa jika satu orang sudah mati untuk semua orang, maka mereka semua sudah mati. Dan Kristus telah mati untuk semua orang, supaya mereka yang hidup, tidak lagi hidup untuk dirinya sendiri, tetapi untuk Dia, yang telah mati dan telah dibangkitkan untuk mereka." Alkitab berkali-kali mencatat tentang kasih Allah kepada orang-orang berdosa. Bagi Paulus, kasih Kristuslah yang menguasai dan mendorongnya untuk memberitakan Injil, sehingga ia rela mengorbankan miliknya, bahkan memberikan dirinya bagi mereka yang dilayaninya. $^{22}$

Belas kasihan terhadap mereka yang terhilang adalah motif yang tertinggi dan terindah bagi para utusan Injil. Menurut Piper, tanpa motif itu, para utusan Injil kehilangan kerendahan hati untuk membagi keselamatan yang telah mereka terima dengan cuma-cuma. Sebab bagi Piper, bahwa belas kasihan kepada mereka yang terhilang tidak dapat dipisahkan dari gairah untuk memuliakan Allah.23 Jadi, bahwa motif belas kasihan dan motif untuk memuliakan Allah bukan dua hal yang terpisah.

Sebab itu, tanpa melebih-lebihkan, dapat dikatakan bahwa jika seseorang pergi mencari jiwa-jiwa yang sesat dengan dorongan/motivasi yang lain dari kasih Kristus, maka sikapnya terhadap orang yang dilayani tidak akan sesuai kehendak-Nya. Itu berarti ia tidak berada dalam keselarasan dengan rancangan keselamatan. Tetapi, kalau seseorang merenungkan kasih Kristus yang begitu

\footnotetext{
${ }^{22}$ Thomy J. Matakupan, 8

${ }^{23}$ John Piper, Jadikan Sekalian Bangsa Bersukacita: Supremasi Allah dalam Misi, 55
} 
besar dan murni hingga rela mati di kayu salib, akan tergerak oleh kasih itu untuk pergi memberitakan Injil. Dengan kasih Allah inilah beribu-ribu misionaris rela meninggalkan keluarga mereka, bangsa mereka, dan menuju tempat yang jauh untuk memberitakan Injil.

Metzger, mengutip pernyataan Piper, mengatakan bahwa perasaan welas asih bagi orang-orang yang terhilang adalah motivasi yang mulia bagi pekerjaan misi. Sebab, tanpa itu, kita kehilangan kerendahan hati yang lembut dalam membagikan harta yang telah kita terima dengan cuma-cuma. Kendati demikian, belas kasihan bagi orang banyak jangan dipisahkan dari kegairahan bagi kemuliaan Allah. ${ }^{24}$

Lagi, John Piper mengatakan, "Jangan menunggu sampai timbul perasaan kasih jika hendak memberitakan tentang Kristus kepada orang asing. Kita telah mengasihi Bapa surgawi kita, dan kita tahu bahwa orang asing ini diciptakan oleh Dia, namun terpisah dari Dia. Jadi, mari kita ambil langkah pertama dalam penginjilan itu karena kita mengasihi Allah. Bukan terutama terdorong oleh belas kasihan pada umat manusia kita membagikan iman kita atau pun mendoakan yang terhilang; tetapi pertama-tama karena kasih kepada Allah.”25

Pernyataan Piper tersebut senada dengan apa yang dikemukakan oleh Spurgeon bahwa di dalam pekerjaan penginjilan tidak boleh dipisahkan dari hukum kasih. Spurgeon mengatakan, "Kita harus mengasihi Allah terlebih dahulu, tetapi ini sama sekali tidak mengurangi kewajiban kita untuk mengasihi orang lain; bahkan perintah yang pertamna mencakup perintah yang kedua. Kita ingin sesama kita bertobat karena kita mengasihi mereka, dan dengan penuh kasih kita harus memberitakan Injil."26

\section{Penginjilan Didorong Juga karena Perasaan Berhutang kepada Allah}

Paulus menyadari dirinya sebagai orang yang berutang kepada Allah, "Aku berhutang baik kepada orang Yunani, maupun kepada orang bukan Yunani, baik kepada orang terpelajar, maupun kepada orang tidak terpelajar. Itulah sebabnya aku ingin untuk memberitakan Injil kepada kamu ...” (Rm. 1:1415). Thomy J. Matakupan menyatakan bahwa "perasaan berutang ini timbul sebagai akibat anugerah keselamatan yang telah diterimanya. Tiada hal lain yang lebih besar untuk membalas kebaikan Allah selain melaksanakan

\footnotetext{
${ }^{24}$ Will Metzger, Beritakan Kebenaran (Surabaya: Momentum, 2013), 205

${ }^{25}$ Will Metzger, Beritakan Kebenaran, 206

${ }^{26}$ Charles H. Spurgeon, Strategi Jitu untuk Menjadi Pemenang Jiwa, 13
} 
penginjilan sehingga orang lain juga dapat mengalami keselamatan yang sama." 27

Perasaan berhutang semacam inilah yang selalu mendesak Paulus untuk memberitakan Injil. Paulus berkata, "Kalau demikian apakah upahku? Upahku ialah ini: bahwa aku boleh memberitakan Injil tanpa upah, dan bahwa aku tidak memergunakan hakku sebagai pemberita Injil" (1 Kor. 9:18). Paulus bermaksud mengajarkan bagi orang Kristen bahwa pelayanan pemberitaan Injil bukan untuk mencari atau mendapatkan upah. Upah tidak boleh menjadi motiv/dorongan dari pekerjaan penginjilan maupun pelayanan apapun bentuknya. Sebaliknya Paulus tidak pernah mengeluh dan menuntut upah dari jemaat yang dilayaninya. Paulus berkata, "Perak atau emas atau pakaian tidak pernah aku ingini dari siapa pun juga" (Kis. 20:33).

Penginjilan Dilakukan karena Pengharapan akan Kedatangan Kristus Kedua Kali

Alkitab berkata, "Dan Injil Kerajaan ini akan diberitakan di seluruh dunia menjadi kesaksian bagi semua bangsa, sesudah itu barulah tiba kesudahannya" (Mat. 24:14). Ditegaskan oleh Thomy J. Matakupan bahwa sikap umat Tuhan dalam menantikan kedatangan-Nya ini seharusnya ditunjukkan dengan cara menyelesaikan tugas Penginjilan. ${ }^{28}$

\section{Penginjilan Adalah untuk Memuliakan Allah}

Motivasi tertinggi dalam pekerjaan penginjilan ialah untuk memuliakan Allah, untuk melihat kesempurnaan-Nya terwujud melalui puji-pujian penuh sukacita dari umat-Nya yang telah ditebus. Sasaran agung dari penginjilan ialah kemuliaan Allah (Rm. 11:36; Ef. 1:12). Demikian pula, setiap orang Kristen wajib menyukakan Allah, bukan menyukakan manusia.

Piper mendaftarkan banyak ayat-ayat Alkitab yang dengan sangat jelas dan gamblang menyatakan bahwa sasaran akhir dari pekerjaan penginjilan adalah untuk memuliakan nama-Nya. Allah menciptakan manusia bagi kemuliaan-Nya (Yes. 43:6-7); Allah memanggil Israel bagi kemuliaan-Nya (Yes. 49:3; Yer. 13:11); Yesus melakuakan segala sesuatu ialah bagi kemuliaan nama Bapa-Nya (Yoh. 7:18); Yesus memerintahkan pengikut-Nya untuk melakukan perbuatan-perbuatan baik sehingga Allah dimuliakan (Mat. 5:16);

\footnotetext{
${ }^{27}$ Thomy J. Matakupan, 9

${ }^{28}$ Thomy J. Matakupan, 9
} 
Allah memberitahu umat-Nya agar melayani Dia dengan cara yang memuliakan nama-Nya (1 Ptr. 4:11), dan sebagainya. ${ }^{29}$

\section{Pentingnya Penginjilan}

Memahami arti penting penginjilan adalah perlu. Menurut Thomy J. Matakupan di dalam bukunya "Prinsip-prinsip Penginjilan", menjelaskan bahwa pentingnya penginjilan didasarkan pada beberapa pertimbangan penting yang menjadi dasar bagi orang Kristen dalam melakukan penginjilan, dijelaskan sebagai berikut: ${ }^{30}$

\section{Manusia Tersesat Akan Binasa Tanpa Kristus.}

Menurut Alkitab, keadaan manusia berdosa adalah "sudah mati karena pelanggaran-pelanggaran dan dosa-dosa" (Ef. 2:1), "tanpa Kristus ... tanpa pengharapan dan tanpa Allah di dalam dunia" (Ef. 2:12), dan "sedang menuju kebinasaan di bawah murka Allah" (Yoh. 3:16,36). Masalahnya, orang berdosa tidak menyadari keberadaannya yang demikian. Jadi, penginjilan dilakukan untuk menyadarkan manusia akan keberadaan dirinya sebagai orang berdosa di hadapan Allah.

\section{Manusia Berdosa Tidak Mampu Menyelamatkan Dirinya Sendiri}

Sesungguhnya sejak dalam kandungan semua manusia sudah mati dalam dosa (Rm. 3:23). Semua manusia keturunan Adam dilahirkan di dalam keadaan yang sama dengan Adam, yaitu berdosa (Rm. 5:12-21). Artinya, semua manusia dilahirkan dengan membawa dosa asal, bahkan semenjak di dalam kandungan (Mzm. 51:7). Dosa Adam itu disebut dosa asal karena bermula pada manusia pertama dan akan terus hadir dalam kehidupan setiap orang semenjak kelahirannya. Dosa asal inilah yang menjadi akar dari dosa-dosa lainnya. Dosadosa yang diperbuat manusia memertegas bahwa natur manusia itu berdosa.

Secara rohani, manusia itu mati. Hal itu ditegaskan di dalam Efesus 5:12 bahwa manusia sudah mati secara rohani, terputus persekutuan dengan Allah, dan kondisi ini menjadikan seluruh manusia keturunan Adam adalah orangorang berdosa. Orang berdosa disebut "mati di dalam dosa". Dan juga ditegaskan di dalam Efesus 2:1, "Kamu dahulu sudah mati karena pelanggaranpelanggaran dan dosa-dosamu".

${ }^{29}$ Selengkapnya dapat dilihat di John Piper, Jadikan Sekalian Bangsa Bersukacita: Supremasi Allah dalam Misi, 18-24

${ }^{30}$ Thomy J. Matakupan, Prinsip-Primsip Penginjilan, 16. 
Dengan demikian, dapat disimpulkan bahwa peristiwa kejatuhan manusia dalam dosa mengakibatkan mereka hidup dalam keberdosaan. Semua manusia keturunan Adam berada di dalam keadaan dan status yang sama. Manusia telah berdosa (Rm. 3:9,10,23). Manusia berdosa tidak mampu menolong dirinya sendiri untuk memeroleh keselamatan, walaupun ia berupaya keras (Ef. 2:8-9). Alkitab mengatakan semua upaya manusia untuk memeroleh pengampunan dosa dan berdamai dengan Allah adalah usaha sia-sia di luar anugerah Allah, yaitu di dalam Kristus (Kol. 1:13-14).

\section{Kristus Satu-satunya Jalan kepada Bapa}

Injil adalah kekuatan Allah yang menyelamatkan setiap orang percaya (Rm. 1:16). Alkitab dengan tegas menyatakan Kristus adalah satu-satunya jalan untuk datang kepada Bapa di surga (Yoh.14: 6; 2 Tim. 2:5). Hal senada diungkapkan oleh Stevanus demikian, "Tuhan Yesus menunjukkan bahwa satusatunya yang diutus untuk menjangkau manusia sehingga manusia bisa mengenal Bapa di surga dan bersekutu dengan Bapa adalah Yesus Kristus sendiri (Yoh.17:3). Kristuslah Perantara satu-satunya antara Allah dan manusia (Ibr.7:25; 8:6; 9:15; 12:24)". ${ }^{31}$ Dengan demikian, dapat dikatakan dengan tegas bahwa Yesus Kristus adalah satu-satunya jalan kepada Bapa di surga. Hanya melalui Kristus saja seseorang dapat kembali kepada Bapa di surga (Kis.4:12).

\section{Tujuan Penginjilan}

Adapun tujuan dari penginjilan, dapat dijelaskan sebagai berikut:

\section{Penginjilan Dilakukan untuk Keselamatan Manusia Berdosa}

Pertanyaan umum yang sering diajukan orang-orang yang memiliki paham universalisme, apakah supremasi Kristus berarti bahwa Ia adalah satu-satunya jalan keselamatan. Apakah Kristus adalah satu-satunya pengharapan bagi umat manusia? Menurut Piper, paham universalisme tidak menolak bahwa Kristus adalah Kurban yang Allah sediakan bagi orang-orang Kristen, tetapi menurut mereka bagi orang-orang non-Kristen atau agama-agama lainnya ada jalan lain untuk diterima oleh Allah dan untuk memeroleh kebahagiaan kekal. Menurut mereka karya Kristus berguna bagi orang-orang Kristen, tetapi tidak demikian halnya bagi dunia atau orang-orang non-Kristen. Kaum universalisme menyatakan bahwa semua agama "sama", walupun masing-masing memiliki

\footnotetext{
${ }^{31}$ Kalis Stevanus, Lihatlah Sang Juruselamat Dunia, 38.
} 
penekanan yang berbeda. ${ }^{32}$ Dengan perkataan lain, tidak ada satu agama untuk seluruh dunia. Kekristenan pun tidak lebih unggul dari keyakinan atau agamaagaman lain, melainkan kekristenan merupakan partner dalam pencarian keselamatan. Pendapat universalisme tidak sesuai dengan apa yang dikemukakan Alkitab di mana Kristus memerintahkan umat-Nya atau gerejaNya pergi untuk menjadikan segala bangsa murid-Nya (Mat. 28:19-20; Kis. $1: 8)$.

Seperti Alkitab katakan bahwa manusia berdosa tersesat seperti domba yang tak bergembala (Mrk. 6:34). Dan Kristus diutus ke dalam dunia untuk mencari dan menyelamatkan yang hilang (Luk. 19:10). Paulus merasa didesak oleh Tuhan untuk menyampaikan Injil bagi keselamatan banyak orang (Fil. 1:23). Paulus meminta orang berdosa untuk berdamai dengan Allah melalui perantaraan Kristus (2 Kor. 5:20). Bahkan Paulus rela menjadikan dirinya hamba dari semua orang agar dapat memberitakan Injil bagi keselamatan orang berdosa (1 Kor. 9:19-22). ${ }^{33}$

\section{Penginjilan Selalu Berkaitan dengan Kerajaan Allah}

Di dalam Matius 4:23 dikatakan, "Yesus pun berkeliling di seluruh Galilea; Ia mengajar dalam rumah-rumah ibadat dan memberitakan Injil Kerajaan Allah serta melenyapkan segala penyakit dan kelemahan di antara bangsa itu". Melalui penginjilan, Kerajaan Allah dinyatakan dalam dunia, karena dengan pertobatan orang berdosa Kerajaan Alah direalisasikan. Menurut pernyataan Kristus sendiri di dalam Matius 28:18, istilah Kerajaan Allah berarti kekuasaan Kristus atas semua yang ada di alam semesta, suatu pengakuan bahwa Kristus adalah Raja di dalam semua aspek kehidupan manusia. Karena itu, Kristus memiliki kedaulatan penuh untuk memerintahkan umat-Nya atau gereja-Nya pergi untuk menjadikan segala bangsa murid-Nya. ${ }^{34}$

\section{Penginjilan Harus Bertujuan untuk Membawa Manusia Melihat Kemuliaan Allah}

Pernyataan Jonathan Edward yang dikutip Piper dengan penyelidikan ayat demi ayat Alkitab, menyimpulkan bahwa: "Tujuan akhir karya Allah, yang

${ }^{32}$ John Piper, Jadikan Sekalian Bangsa Bersukacita: Supremasi Allah Dalam Misi, 195.

${ }^{33}$ Kalis Stevanus, Penggilan Teragung: Pedoman Dan Metoda Praktis Untuk Memberitakan Kabar Baik Sampai Ke Ujung Bumi, 66.

${ }^{34}$ Thomy J. Matakupan, Prinsip-Primsip Penginjilan, 10. 
dengan berbagai cara diungkapkan di dalam Alkitab, hanyalah satu, yang satu ini paling tepat disebut kemuliaan Allah".35

Penginjilan harus bertujuan untuk membawa manusia melihat kemuliaan Allah. Ketika kehendak Allah dilakukan, maka Ia dimuliakan. Paulus menyatakan bahwa di dalam kekekalan Allah telah menetapkan karya penebusan Kristus, dan tujuan dari semua pekerjaan Allah ialah, "supaya terpujilah kasih karunia-Nya yang mulia" (Ef. 1:6), dan "supaya kami ... boleh menjadi puji-pujian bagi kemuliaan-Nya" (Ef. 1:12,14). ${ }^{36}$

Dapat disimpulkan bahwa tujuan akhir Allah ialah memuliakan nama-Nya dan menikmati diri-Nya selama-lamanya. Dialah satu-satunya yang layak dimuliakan di muka bumi ini. Sebab itu, sudah semestinya gairah untuk memuliakan Allah memotivasi pekerjaan penginjilan ke seluruh dunia, "agar bangsa-bangsa dapat memuliakan Allah karena rahmat-Nya” (Rm. 15:9)

\section{Simpulan}

Penginjilan berkaitan erat dengan pengakuan iman Kristen bahwa Yesus Kristus adalah satu-satunya jalan keselamatan atau satu-satunya Juruselamat bagi manusia berdosa. Berdasar keyakinan tersebut, maka penginjilan menjadi hal yang mutlak dilakukan dan sangat diharapkan bagi mereka yang belum percaya dan menerima Yesus Kristus sebagai Juruselamat dan Tuhan di dalam hidupnya. Perintah atau mandat untuk memberitakan Injil tidak pernah menjadi sebuah amanat yang usang karena perkembangan zaman. Dalam hal ini, gereja atau orang-orang yang telah percaya Yesus Kristus yang diberikan mandat untuk memberitakan Injil kepada semua manusia tanpa terkecuali pada segala tempat dan pada segala zaman. Injil harus terus diberitakan sampai pada kedatangan kedua dari Tuhan Yesus. Pada konteks kekinian pun, penginjilan tetaplah merupakan sebuah "keharusan" dilakukan oleh setiap orang Kristen, dan penginjilan merupakan hal yang urgen bagi manusia pada masa kini. Berita Injil itu harus dibawa oleh setiap orang Kristen ke dalam dunia non-Kristen dan ditanamkan di dalam hati setiap manusia berdosa. Ini sebuah pekerjaan yang tidak mudah, tetapi juga tak terhindarkan. Dunia non-Kristen merupakan ladang misi di mana Injil harus disemaikan di ladang tersebut supaya banyak orang diselamatkan. Sebab manusia berdosa hanya bisa didamaikan dengan Allah melalui perantaraan imkan kepada Kristus. Manusia berdosa dapat diselamatkan, maka harus mendengar Injil dan menerima undangan Injil

\footnotetext{
${ }^{35}$ John Piper, Jadikan Sekalian Bangsa Bersukacita: Supremasi Allah Dalam Misi, 26.

${ }^{36}$ Thomy J. Matakupan, Prinsip-Primsip Penginjilan, 10.
} 
tersebut dengan sepenuhnya menyambut Kristus sebagai Tuhan dan Juruselamat pribadinya.

\section{Daftar Pustaka}

Charles H. Spurgeon. Strategi Jitu Untuk Menjadi Pemenang Jiwa. Yogyakarta: Andi, 2019.

Hannas dan Rinawaty. "Menerapkan Model Penginjilan Pada Masa Kini" KURIOS (Jurnal Teologi dan Pendidikan Agama Kristen), Vol. 5, No. 2 (2018).

Howard G. Hendricks. Beritakan Injil Dengan Kasih. Jakarta: BPK Gunung Mulia, 2008.

J. I. Packer. Penginjilan Dan Kedaulatan Allah. Surabaya: Momentum, 2003.

John Piper. Jadikan Sekalian Bangsa Bersukacita: Supremasi Allah Dalam Misi. Bandung: Literature Baptis, 2001.

Kalis Stevanus. "'Mengimplementasikan Pelayanan Yesus Dalam Konteks Misi

Masa Kini Menurut Injil Sinoptik"." Fidei: Jurnal Teologi Sistematika dan

Praktika Vol.1, No. No.2 (Desember 2018).

—. Jalan Masuk Kerajaan Surga. Yogyakarta: Andi Offset, 2017.

—. Lihatlah Sang Juruselamat Dunia. Yogyakarta: Diandra Kreatif, 2018.

- Penggilan Teragung: Pedoman Dan Metoda Praktis Untuk Memberitakan Kabar Baik Sampai Ke Ujung Bumi. Yogyakarta: Andi Offset, 2019.

V. Scheunemann. Apa Kata Alkitab Tentang Dogma Kristen. Malang: YPPII, 1992.

Stephen Tong. Teologi Penginjilan. Jakarta: Lembaga Reformed Injili Indonesia, 2004.

Stevanus, Kalis. Benarkah Injil Untuk Semua Orang. Yogyakarta: Diandra Kreatif, 2019.

Thomy J. Matakupan. Prinsip-Primsip Penginjilan. Surabaya: Momentum, 2002. Tomatala, Yakob. Penginjilan Masa Kini 1. Malang: Gandum Mas, 2004. Will Metzger. Beritakan Kebenaran. Surabaya: Momentum, 2013. 